\title{
Fetal citizens? Birthright citizenship, reproductive futurism, and the 'panic' over Chinese birth tourism in southern California
}

Accepted (pending revisions) for Environment and Planning D: Society and Space theme section, "Race, Biopolitics, and the Future"

Sean H. Wang

Department of Geography

Syracuse University

144 Eggers Hall

Syracuse, NY 13244-1020

shwang13@syr.edu

Acknowledgements: This material is based upon work supported by the National Science Foundation Graduate Research Fellowship under Grant No. 1247399. Any opinions, findings, and conclusions or recommendations expressed in this material are those of the author and do not necessarily reflect the views of the National Science Foundation. Syracuse University provided additional support in the form of a Maxwell School Roscoe-Martin Award. Many thanks to Chandra Mohanty, Deborah Pellow, Erin Rand, Robin Riley, and Jamie Winders for their critiques on previous iterations of this paper, He Wang for her support during writing, Sara Smith and Pavithra Vasudevan for all their work putting together this theme section, and the editor and reviewers for their generous comments and suggestions. 


\title{
Fetal citizens? Birthright citizenship, reproductive futurism, and the 'panic' over Chinese birth tourism in southern California
}

\begin{abstract}
In September 2012, residents of Chino Hills, California - a wealthy suburb of Los Angeles - exposed a maternity hotel in their city. Subsequently, controversy erupted as protesting residents argued that Chinese birth tourism is an immigration loophole, where foreigners took advantage of jus soli birthright citizenship guaranteed by the Fourteenth Amendment to the U.S. Constitution. This paper uses this controversy as a springboard to explore how temporalities - both the past and the future - come to shape politics in the present. Considering reproductive futurism in the context of citizenship and migrations, this paper argues that the figure of the fetal citizen emerges as the defining site of struggle between preserving, or exposing, the fantasy of a national future. Reports of panic over Chinese birth tourism, then, show how 'backwards' racialized citizenship is continually brought to this present struggle, especially vis-à-vis discourses of the 'worthy immigrant' and 'anchor babies', to determine who may give birth to citizens in the U.S.
\end{abstract}

Keywords: birthright citizenship, reproductive futurism, birth tourism, immigration, temporality, critical media studies

In September 2012, residents of Chino Hills, California—a wealthy suburb in San Bernardino County—reported a sewage spill from a hillside mansion. According to media reports, first by a local newspaper, then by the Los Angeles Times, and finally by various national media outlets, local residents had been suspicious of the goings-on at this mansion for a long time because people who lived there did not seem friendly and kept to themselves. With the sewage spill and the subsequent code inspection, the mansion was exposed as a 'maternity hotel'. The owner had subdivided the house into numerous rooms to accommodate more than ten Chinese women at a time. He had installed a commercial-grade kitchen and hired cooks and nurses to look after the women staying there, waiting to give birth (PBS, 2013).

When code violations are found, a citation is usually issued and the investigation ends once the building is brought up to code. However, a few Chino Hills residents, upon learning about this code violation citation, picketed the mansion for what they saw as an instance of 'illegal immigration'. They argued that these pregnant women and their families took advantage of the U.S. Constitution to secure citizenship for their children_-so-called 'anchor babies'—and, eventually, their entire extended family. After forming a group called "Not in Chino Hills!" (NICH), these residents began lobbying local politicians to address this supposed immigration loophole. NICH members flooded municipal and regional council meetings in the San Gabriel Valley, voicing their concerns about welfare-cheating and burdens on taxpayers to local governments. Their civic participation prompted Los Angeles County Councilman, Don Knabe, to set up a multi-agency 
taskforce to look into this issue. The Los Angeles Times ran a series of 16 articles on the Chino Hills controversy. By July 2013, the maternity hotel in Chino Hills was abandoned.

The Chino Hills controversy appears to be yet another instance in a long history of antiimmigration organizing in the U.S., but a closer look into it reveals a reworking of race and immigration vis-à-vis changing biopolitics in the U.S. In particular, local interpretations of birth tourism as 'immigration loopholes' in southern California highlight the nexus of reproduction, citizenship regimes, and racial formations - a nexus that brings historical xenophobia to the forefront. In this paper, I develop a theoretical framework that foregrounds temporality to situate and explain the contemporary formation of this nexus. The Chino Hills controversy, I argue, demonstrates how constructions of political arguments ostensibly about the present must always rely on a (re)telling of the past and a vision of the future. Said differently, temporality itself is constitutive of politics in the present, and it is precisely the collapsing of the past and the future that distinguishes the contemporary mode of biopolitics.

Following this introduction, I unfurl my argument in three sections. The first provides context on the practice of birth tourism and situates its emergence within southern California's racialized history and landscape. It also introduces my research methodology. The next two sections interweave results from critical media analysis of the Chino Hills controversies with theoretical arguments about the temporality of contemporary citizenship politics. I first focus on the past by historicizing birthright citizenship in the U.S. Tracing the racialized history of jus soli (right of the soil) in the U.S., specifically its anti-Asian origins, I argue that citizenship regimes have always relied on ideas about biopolitical reproductions of the ideal national body (Tyler, 2010). I then link this past to competing political visions of the future through a discussion of contemporary immigration politics. Using the language of reproductive futurism, I demonstrate how anti-immigration politics in particular are conducted through a temporal mode of control that relies on anxieties about the future. In particular, this move relies on replacing the present with a future "imagined for fetuses and children", thus bringing the figure of the fetal citizen to the forefront of immigration politics (Berlant, 1997, page 1). The textual analysis of media reports on birth tourism in these two sections together demonstrates how immigration politics are worked through the figure of the fetal citizen in the Chino Hills controversy.

$\underline{\text { Contexts and Method }}$ 
Usually considered a form of medical tourism, birth tourism (or 'maternity tourism'/'maternity migrations') describes the practice where pregnant women cross international borders to receive maternity care and give birth (Connell, 2013; Roberts and Scheper-Hughes, 2011). Although motivations behind birth tourism vary, many opponents point to the lure of citizenship for either expectant mothers or their children as a significant pull factor. Birth tourism, in this representation, is made possible by jus soli birthright citizenship laws. Dubbed 'citizenship tourism', these cases occur globally and although small in number compared to immigrant populations at large, they have figured prominently in recent citizenship debates in both Canada (Mas, 2014; Wong, 2014) and the U.S. (Jacobson, 2010).

In southern California, birth tourism has become a lightning rod in state-wide fights over 'illegal immigration', where anti-immigration politicians and activists have argued that the Fourteenth Amendment to the U.S. Constitution, which grants citizenship on the jus soli basis, is driving birth tourism to the U.S. and should be abolished. This claim is often made with offensive and incendiary language, describing pregnant migrant women_especially Latinas_as "multiplying rats" (Cisneros, 2013, page 291) and their children as "anchor babies" (Lederer, 2013; Ignatow and Williams, 2011). Through these political debates over birthright citizenship, a nascent racial politics is emerging in the U.S. Asians and Latinos are both perceived as threats, but Latinos are seen as stereotypical poor migrants strategizing to remain in the U.S. (Tobar, 2011), while Asians are seen as using their financial clout to buy their way in instead (Lu, 2014; Beech, 2013). As one Californian antiimmigration activist put it though, whether Mexican 'anchor babies' or Chinese birth tourism, “[i]t's invasion by birth canal" (Templeton, 2010).

It is important to understand the spatial context of these anti-immigration responses, as they emerge at the nexus of existing ethnic settlements and particular racial formations in southern California. This paper follows the assumption that migrations and other population movements result in changing co-configurations of race and place (Price, 2012; Smith and Winders, 2008; Liu, 2000). Most reports of Chinese birth tourism have emerged from San Gabriel Valley, a suburban region of nearly 400 square miles that stretches from the east of Los Angeles all the way to the Inland Empire, bracketed by the San Gabriel Mountains to the north and Orange County to the south. ${ }^{1}$ With around two million residents - roughly one-fifth of Los Angeles County's total

${ }^{1}$ This San Gabriel Valley profile is condensed and synthesized from three primary sources - Cheng (2013), Pulido et al. (2012), and Ochoa (2004) - and supplemented by U.S. Census data, online public history entries (Rojas, 2014; South El Monte Arts Posse, 2014), and my own personal knowledge. 
population - it is also the largest majority Asian and Latino region in the U.S. This area underwent rapid suburbanization post-World War II, and redlining and other discriminatory practices initially limited where non-white residents could live, creating unique residential geographies of racial mixing that remain today. Now, San Gabriel Valley is home to places with nicknames like 'Little Taipei', 'Suburban Chinatown', and 'Mexican Beverly Hills', where new migrants of diverse backgrounds continue to arrive and settle. Chino Hills is at the eastern edge of San Gabriel Valley and actually part of San Bernardino County. In contrast to earlier reports of Chinese maternity hotels, most of which came from the heart of San Gabriel Valley, where residents tend to come from mixed socioeconomic backgrounds, Chino Hills is an extremely wealthy city and has been included in several 'Best Places to Live' rankings nationally. This shift mirrors national studies of immigration in the U.S., where focus has shifted from traditional gateway regions at-large (such as southern California; Massey, 2008; Pandit and Holloway, 2005) to non-white migrations to the suburbs (Ellis et al., 2014; Jones, 2008). It is especially prominent in traditional immigrant gateway regions, where internal migrations of long-time residents and recent arrivals directly to the suburbs have together created the "ethnoburbs": multi-ethnic suburban communities in metropolitan regions (Li, 1998). In other words, although immigrants are still arriving in large numbers to gateway cities, they are settling in different parts within them, suggesting a regional shift vis-à-vis reception contexts (Singer et al., 2008; Ellis, 2006).

Specific to this paper, long histories of Asian immigration and settlement in southern California have led to comparatively large concentration of Asian residents ${ }^{2}$ and an explosion of ethnoburbs since the 1990s (Li, 2009). San Gabriel Valley is, incidentally, the most prominent ethnoburb in the literature (Zhou et al., 2008; Lin and Robinson, 2005; Li, 1999). In other words, the Chinese birth tourism industry is happening where there is already a large, established ChineseAmerican community (Tseng, 1994), but little work has been done to show how the continuing influx of Chinese migrants might affect existing racial formations there (cf. Mitchell, 1998). This paper only begins to scratch at the surface of this investigation, and only superficially at that. Nonetheless, evidence suggests that Chinese maternity hotels are now edging out to more exclusive residential areas, and this shift helps contextualize the more intensive media reporting on the Chino Hills controversy compared to similar incidents in the past (cf. Medina, 2011).

\footnotetext{
2 According to the U.S. Census 2010, Asians comprise 14.9\% of the total population in California compared to only 5.6\% nationally (Hoeffel et al., 2012).
} 
It is from this demographic and political context that the panic over Chinese birth tourism emerged in southern California. To make sense of the anti-immigration and anti-jus soli rhetorics surrounding the Chino Hills controversy, this paper employs textual analysis that considers newspaper and online media reports on the Chino Hills controversy. The media materials include all reporting done on the Chino Hills controversy by the Los Angeles Times (the major national newspaper in southern California), as well as select regional and national media outlets. Only select ethnic media from the region are also included, and I have restricted materials under consideration to those published in English. I made this decision because my goal for this paper is to explore how the dominant framing of the Chino Hills controversy became focused on anti-jus soli logic to the exclusion of other aspects of Chinese birth tourism, and this was accomplished largely through English-language reporting in national media outlets in the U.S. (see Koch, in press). Textual analysis of media reports is supplemented by various official documents produced to address the Chino Hills controversy. The documents under review include materials published by NICH online, as well as meeting minutes from various city and county councils in the region where the issue of Chinese birth tourism was under debate. My textual analysis is contexualized and deepened by interviews both on- and off-the-record with a number of local residents, stakeholders, and those involved in birth tourism operations conducted in March 2014 and June-July 2015, though I have largely relegated information gained from these avenues to the background of textual analysis. In this regard, my paper follows a tradition of critical media studies (e.g., MacDonald, 2016), especially those exploring how media produce dominant framings in immigration and citizenship debates (Lederer, 2013; Ignatow and Williams, 2011; Cisneros, 2008).

Accordingly, the next two sections read media reports and other documents on the birth tourism controversy in Chino Hills not to certify their accuracy, but to see what imaginaries they simultaneously draw upon and (re)produce. I do not suggest that media representations constitute the whole of social discourse on race, immigration, and citizenship in southern California, but they are a crucial part of it nonetheless. In these readings, the figure of the fetal citizen emerge as a site of politics temporally, both 'backwards' in a call to racist legacies of citizenship laws and 'forward' in an attempt to cast these legacies onto the pregnant Chinese women and their unborn children. The institution of jus soli, then, functions as a last-resort legal shield for maternal rights for these women, even when invoking such a defense erases their own autonomous subjectivity and encourages antiimmigration campaigners to advance what Cisneros (2013) describes as 'backwards uncitizening'. To draw out these themes, I synthesized scholarships on the history of birthright citizenship in the U.S. 
and queer theory of reproductive futurism, and interweaved them with results of textual analysis, in the next two sections.

In delimiting the scope of this paper to textual analysis of media and documents, I made certain methodological decisions that deserve further discussions here. The first has to do with selection of evidences under consideration. By largely focusing on reporting on birth tourism by national media outlets in the U.S. (at the expense of, say, reports by Chinese media), I risk unintentionally legitimating the existing anti-immigration framing in U.S. media by giving it yet another platform over alternative representations. ${ }^{3} \mathrm{I}$ have nonetheless decided to take this risk, however, because my goal for this paper is to explore precisely the seeming rise of this 'panic' over birth tourism vis-à-vis dominant ideologies like reproductive futurism, and mainstream media outlets are central to the legitimation of this dominance (Koch, in press). I hope that instead of unreflexively privileging dominant narratives of birth tourism, textual analysis in the next section adequately demonstrates how the figure of the fetal citizen, both the ones already here and the ones that may come in the future, becomes central to a range of political arguments around the Chino Hills controversy.

This leads to a second decision on the overall framing of my argument that I must elaborate on. While the practice of birth tourism is inherently transnational, this paper does not explicitly engage with the transnationalism and flexible citizenship literature (Ong, 1999; see Lin, 2012 for a relevant critique). This is because the focus of this paper is not to explore the motivations behind, and the logistics of, engaging in birth tourism (which requires sustained and multi-sited ethnography). ${ }^{4}$ Instead, following similar work in rhetorical studies (e.g., Yam, in press), I restrict my geography to the receiving locale and analyze how anti-immigration sentiments are mediated through news reports in southern California in the absence of - and even in spite of - any accurate representation of birth tourism transnationally (Koch, in press; 2013). Said differently, the goal of

\footnotetext{
${ }^{3}$ It is important to note that such alternative representations about the intent behind, and the meaning of, birth tourism are numerous in China, and very few of them were included in reporting by U.S.-based media. For instance, the Chinese romantic comedy Finding Mr. Right (2013), whose protagonist engaged in birth tourism in Seattle, was a box-office hit and sparked intense cultural debates online among Chinese netizens regarding Chinese desires for U.S. citizenship.

${ }^{4}$ For an example of such a study on Turkish birth tourism to the U.S., see Balta and Altan-Olcay, 2015. I am currently engaging in exactly this transnational ethnographic project on Chinese birth tourism, though I have been frequently and forcefully reminded of why comprehensive transnational ethnographies are few and far between: transnationalism is difficult to operationalize into specific activities, and methodological challenges abound (Levitt and Jaworsky, 2007). Most research activities in migration studies remain transnational in frame only, though there are notable exceptions through techniques like "follow-the-people" (cf. Buscher and Urry, 2009; Smith, 2005; Hannerz, 2003).
} 
this paper is to link across scales how media representations of birth tourism controversies in southern California reflect and reinforce dominant ideologies on racialized reproductive futurism in the U.S. It is to this critical media analysis at the regional scale that I now turn.

\section{Birthright citizenship and the history of racial exclusions}

Birth tourism is controversial in large part because theoretically, it could provide a legal route to citizenship for not just the newborns at birth, but eventually their entire families. In southern California, allegations of 'illegal immigration' and welfare-cheating comprise the major responses during the Chino Hills controversy. Nationally, anti-immigration politicians and activists have argued that the Fourteenth Amendment to the U.S. Constitution, which grants citizenship on a jus soli basis, is driving birth tourism to the U.S. and should be abolished. But what is it about the legal mechanism of birthright citizenship that elicits such strong reactions? To understand xenophobic responses to Chinese birth tourism, this section surveys the history of jus soli birthright citizenship in the U.S. and-following feminist, queer, and critical legal studies-argues that the racialized history of U.S. citizenship continues to shape current efforts to repeal jus soli in the U.S.

Birthright citizenship, the legal mechanism through which one acquires national citizenship at birth either by right of blood (jus sanguinis) or soil (jus soli), is increasingly under debate across the world (Aleinikoff and Klusmeyer, 2002). In the past two decades, a number of decisions have sought to limit transnational migrations by limiting or eliminating the jus soli principle in nations like Ireland (Luibhéid, 2013; Conlon, 2010; Tormey, 2007) and India (Sadiq, 2008) or severely restricting its application in Australia, New Zealand, and South Africa, just to name a few (Mancini and Finlay, 2008). Currently, the U.S. and Canada are the only remaining developed countries that observe jus soli with little to no restrictions. Political theorists interpret these events as logical results of globalization confronting now-outdated citizenship laws (Isin, 2012; cf. Bloemraad et al., 2008), with many proposing alternative ones for the future (Bauder, 2014; Shachar, 2009; Stevens, 2009). While many proposals of alternative citizenship laws are progressive and even utopian in nature, they risk deflecting attention from critically analyzing why and how birthright citizenship laws have become more restrictive, as well as identifying who is most vulnerable to these new restrictions.

Furthermore, they do not adequately account for the emotional connection between legal citizenship and national belonging that often drives both pro- and anti-immigration rhetorics in the U.S.

(Chavez, 2013; Cisneros, 2008; Somerville, 2005). 
To address these shortcomings, feminist and queer theorists have collectively identified discourses that drive the trend of curtailing jus soli citizenship laws. Demonstrating that laws are "social production at its most literal" (Cresswell, 2006, page 158), such scholars argue that changes in birthright citizenship laws often reflect prevailing attitudes on national belonging and criteria for exclusion (Menzel, 2013; Molina, 2013; Ngai, 2005). In particular, birthright citizenship laws have become a tool for nation-states to control international migrations by targeting pregnant migrants' mobility and reproductive rights (Constable, 2014; Cisneros, 2013; Luibheid, 2013; Hartry, 2012). States often justify these xenophobic tactics by invoking enduring racial and sexual contagion narratives (Tchen and Yeats, 2014; Cisneros, 2008) and scapegoating migrants for the declining welfare state (Oliviero, 2013; Tyler, 2010; Glenn, 2000), both common themes in anti-immigration rhetorics. These works collectively demonstrate that although birthright citizenship laws are crucial in producing legal citizens, a narrow, legalistic framework is insufficient to understand how legal categories of citizenship are contested vis-à-vis feelings of national belonging.

Specific to the Chino Hills controversy, the group (the Chinese) and the institution (jus soli) under attack have an intertwined and, at times, contradictory history in the U.S. This history is solidified in the various Chinese Exclusion Acts since 1884 (not repealed until 1943) and the 1898 Supreme Court ruling in United States v. Wong Kim Ark, but it is insufficient to reduce this history to legal decisions only. Rather, the debates during these decisions reveal how birthright citizenship laws were seen as crucial in producing national futures. Said differently, citizenship laws put particular ideas about race and immigration into practice, so fights over these laws are precisely fights over which conceptions of race, immigration, and the nation would prevail. For example, historian Mae Ngai characterized anti-jus soli campaigns as a logical extension of racial exclusion laws. Even prior to Wong Kim Ark, "anti-Chinese nativists [already] understood that granting citizenship to the children of Chinese assured permanent settlement and an accretion of the Chinese population, thereby undermining the very objectives of exclusion" (Ngai, 2007, page 2528; emphasis added). And more than a century later, the same rhetoric of securing the future nation against racial contagions continues to animate anti-jus soli campaigns (Oliviero, 2013; Tormey, 2007) and anti-immigration organizing more generally (e.g., Cisneros, 2008).

This racial history of jus soli features prominently in responses to the Chino Hills controversy. Media reports of birth tourism are largely negative, and two figures appear frequently in these reports - Los Angeles county councilman Don Knabe and NICH's de facto leader Rossana Mitchell. A prominent media strategy of theirs is to question jus solis legal basis, but only when it is 
applied to those already deemed unfit (mothers of) citizens based on racialized criteria. Both Knabe and Mitchell have repeatedly stated these Chinese birth tourists are exploiting a U.S. "citizenship loophole”, despite the state's official stance that maternity hotels are a zoning issue, not an immigration issue. ${ }^{5}$ Characterizing certain applications of jus soli as loopholes continues a trend of gradually chipping away at supposedly universal citizenship laws for those who are already most vulnerable (Berlant, 1994, page 149). Mitchell, in particular, drew heavily from the trope of 'worthy immigrants' (Nair, 2011) to demarcate those who belong in the U.S. nation - and thus deserving of jus soli - from those who do not. In a filmed interview, Mitchell spent considerable time recounting her status as an authentic and rule-following American immigrant: "On an ethical level, I think [birth tourism] is very concerning, it's not very American... As an immigrant myself - I came here when I was eight years old; my father came over here, first, left our entire family, worked two jobs, earned enough money to send visas for our family... We are all citizens now, we're very proud to be Americans, and we worked really hard at it. Essentially, birth tourism is like buying citizenship" (PBS, 2013). For Mitchell, not having the same degree of investment - that is, the same degree of proper desire for your inclusion within the nation (cf. Somerville, 2005) - makes you a suspect national subject immediately.

Racist sentiments expressed as supposed concern for the future remain striking in contemporary citizenship debates in the U.S. Take Schuck and Smith's (1985) Citizenship Without Consent for example, where two prominent legal scholars argued that the Fourteenth Amendment should not apply to children of 'aliens' in the U.S. Citizenship, they argued, is based on consent. Accordingly, the Fourteenth Amendment is only applicable to those 'subject to the jurisdiction thereof and, contra-Wong Kim Ark, the jurisdiction in question is primarily political and not territorial. Despite being roundly criticized by constitutional law experts (Aber and Small, 2013), the book has become a foundational text for anti-immigration politicians. Ngai (2007) forcefully argued, however, that "the racial history of citizenship reveals the principle of mutual consent to be a myth" (page 2529). Furthermore, citizenship based on a strong consensual framework in fact enabled racial exclusions, since "[t] he application of consent between a state and an individual is one of grossly unequal power, especially when the state is controlled by a group of individuals - even a democratic majority—that holds prejudice or animus toward another group” (Bloemraad, 2013, page 63). Demonstrating poignantly how the past shapes the future, abolishing jus soli would result in a permanent underclass whose descendants have no possibility ever attaining legal statuses, which -

${ }^{5}$ Compare Knabe's comments in PBS (2013) and Chang (2013c). 
presumably - is exactly what anti-immigration politicians have in mind. And as aforementioned, the Chino Hills controversy came on the heels of a number of international and national decisions that sought to limit 'illegal' immigration by either imposing stricter border restrictions, limiting or eliminating jus soli, or a combination of both.

Following the Chino Hills controversy, this racialized interpellation of citizens is especially reflected in how Asian American residents echoed similar sentiments of the 'worthy immigrants'. Immediately after the first reports of birth tourism in Chino Hills, the Chinese American Association of Chino Hills (CAACH) sent out a letter condemning the practice, citing-in particular-concerns for pregnant Chinese women's well-being and their fetuses' safety (CAACH, 2012). It may seem surprising that Asian American residents are not more sympathetic toward Chinese birth tourists for the length to which they were willing to go to secure U.S. citizenship for their newborns. However, the swift and strong condemnation from Asian American residents (via press release) is not only expected but demanded by the logic of racialized citizenship. Lending credence to Ngai's (1999) argument that Asians remain the 'alien citizen' against which U.S. citizenship secures itself, anything less than a strong condemnation of Chinese birth tourism might result in Asian Americans being portrayed as not patriotic enough. For CAACH, expressions of care for the fetal citizen becomes the vehicle through which this disavowal of more recent and 'irregular' form of Asian migration can be achieved without damaging its own solidified-yet-always-insecure position within southern California's racial formations. So " $[\mathrm{w}]$ hile it is a constitutional freedom for an individual who give [sic] birth in our country and the offspring to be automatically becomes [sic] a U.S. citizen, it is nothing but an exploitation of the same freedom for monetary purposes" (CAACH, 2012). Further, CAACH "is strongly against the existence of maternity hotels, not only in Chino Hills, but in any other communities in the nation it [sic] choose it [sic] operate" (ibid.). In other words, this constitutional freedom is only available for some, i.e., those doing it in the right way', while others are to be spatially excluded from all communities in the nation (see Roberts, 1998).

This racial history of U.S. citizenship, especially its anti-Asian origins, reveals it to be an instrument of racialized violence (Eng, 2010, page 45). Contra citizenship's egalitarian promise, the incorporation of new citizens into the U.S. nation has been a violent process for non-whites. Furthermore, this racialized violence is exercised through a temporal mode of control, stoked by anxieties over a racially impure future. Contemporary struggles over citizenship policies, then, are essentially struggles over differing visions of the national future. In the next section, then, I follow this line of argument to explore how, in the absence of a realistic chance to do away with the 
Fourteenth Amendment, anti-immigration efforts increasingly honed in on women's reproduction as a site of enacting anti-immigration politics.

\section{Racialized reproductive futurism in U.S. immigration politics}

In the Chino Hills controversy, the intertwining nexus of race, citizenship, and reproduction becomes visible in southern California. With the national media portraying it as a flashpoint in immigration debates, birth tourism is transformed into a ground from which political debates over birthright citizenship could erupt. What happens in these political debates when the 'fetal child' is recognized not just as a subject, but as a (potential) citizen? This section addresses this question through the lens of reproductive futurism. Because birthright citizenship provides the legal mechanism through which reproductive futurism functions, manipulating state policies governing women's reproduction becomes a tactic through which the desired national population for the future could be engineered. This focus on the future, especially for how it serves as the conditions of possibility for current politics, is a useful lens to explore birth tourism and the Chino Hills controversy (cf. Katz, 2008; 2011; Mitchell, 2010; Baldwin, 2012; Amin, 2013).

In No Future, Lee Edelman (2004) argues that reproductive futurism is a heteronormative tactic that invokes the imaginary child for whom the society must demand a better future, complete with capitalist success, heterosexual nuclear family, and further reproductions. The figure of the innocent child, then, becomes a "'disciplinary image' that performs the 'mandatory cultural labor of social reproduction"” (Edelman, 2004, page 19 cited in Katz, 2008, page 14). Reproductive futurism discursively casts non-heterosexuals - and gay men, especially - as subjects who do not belong in the future, and their non-reproduction would ultimately result in social death. Scholars writing on futurity have since built on this work (e.g., Enloe, 1990). Here I draw from Eithne Luibhéid's (2013) book Pregnant on Arrival, where she documented the events leading up to Ireland's 2004 decision to abolish its jus soli birthright citizenship in response to the perceived threat of asylum seekers from Africa, to place reproductive futurism in immigration politics. Following Edelman (2004), Luibhéid argued that migrants in Ireland are also abjected, though differently than gay men, through reproductive futurism. The abolishment of jus soli hinged on the Irish state's claim that "migrant women's childbearing threatened... a desirable future for 'properly' Irish citizens” (Luibhéid, 2013, page 150). Since their children were no longer Irish citizens, many migrants then lost their only realistic avenue to gaining legal status. Luibhéid argued that here reproductive futurism has sinister material consequences. Legally, it potentially produces generations of stateless people who are born 
in Ireland but could claim citizenship from neither Ireland nor their parents' country of origin (e.g., Kerber, 2009; Constable, 2014). Not only did the decision "limit [these children's] future entitlements but also render them vulnerable to becoming designated as 'illegal' and deportable in their own right" (Luibhéid, 2013, page 150). Reproductive futurism here was worked by the Irish state to ensure that there is no future for not just migrants, but their children and their children's children as well.

Collapsing the past and the future, reproductive futurism is overdetermined by histories of racialization, something Edelman largely ignored (see also Sziarto paper in this theme section). Luibhéid explicitly argued that the 2004 referendum again re-inscribed Ireland as a white nation. Although migrants' supposed lack of 'genuine connection' to Ireland was used as a justification to abolish jus soli, those of Irish descent born outside of Ireland could still acquire citizenship through jus sanguinis for up to two generations. The families that the Irish state recognizes as 'Irish', then, are explicitly heterosexual and white. Indeed, there is a frightening similarity between the 2004 Irish referendum and the pre-Wong Kim Ark nativists referenced by Ngai (2007) except, in the latter case, their claims were rejected by the U.S. Supreme Court. Geographers writing on futurity and race also have argued (e.g., Mitchell, 2010) that reproductive futurism is never just about the future but always about disciplinary power in the present.

In Chino Hills, histories of Asian immigration and settlement did not produce a 'colorblind' society or 'multicultural harmony'. Instead, Leland Saito (1998, page 8) has suggested that Asian American politics in the region is overdetermined by the physical appearance of 'race', and CAACH clearly wrestles with this dilemma. In the aftermath of the Chino Hills controversy, two particular sets of racial tensions have been documented in the regional media: the first being a general suspicion against Asians, especially pregnant Asian women; the second being the hostility from Asian American residents toward those perceived to be a 'birth tourist'. For the first set of racial tensions, the Los Angeles County Department of Regional Planning reported a huge spike in the number of false complaints of suspected maternity hotels it received following the media reports on Chino Hills. Most of these complaints are based on "groups of pregnant Asian - possibly Chinese women congregating in public" or "...going to a house together". ${ }^{6}$ This particular form of racial profiling against Asian (American) women produced mutual suspicion and feelings of injustice. For example, long-time resident Annie Ren told the Los Angeles Times, "People look at me like, 'Is she from the hotel?' This city wasn't like this before. I grew up here” (Chang, 2012a). The second set of

${ }^{6}$ Interview with member of Los Angeles county taskforce on birth tourism, March 10, 2014. 
racial tensions emerged in response to these feelings. In the aforementioned letter, CAACH (2012) called birth tourism "an outrageous exploitation of the United States constitution" while simultaneously expressing concerns for the well-being of these "innocent pregnant women". NICH then co-opted this letter to demonstrate that their opposition to birth tourism and, more broadly, jus soli is not a 'race issue'.

Here, it is useful to consider reproductive futurism side-by-side with Lauren Berlant's ruminations on fetality and citizenship. In “America, 'fat,' the fetus”, Berlant (1994, page 148) argued that pregnant women have become "vehicle for the production of national culture" in the U.S. Far from empowering women, however, this move was achieved by establishing the condition of fetality via granting the fetus its own citizenship. In a representational maneuver that collapses “the pregnant woman's multidimensional form - its fat, its femaleness, its fetus" into simply a vehicle for reproduction (ibid.), the fetus takes center-stage while the women themselves, like other "members of the politically distressed populations of the United States... get humiliatingly named and reduced to their stereotypic embodiment during moments of distraction or preoccupation" (page 149). Put more simply, “[w]hereas men are 'citizens first' and husbands and fathers only secondarily... women have frequently been conceived of as solely mothers and wives - as maternal producers and containers of citizens rather than as citizens in their own right" (de Beauvoir, 1989 paraphrased in Cisneros, 2013, page 293). For pregnant women, especially, their (non-)citizenship becomes derivative from the fetus-as-citizen. Coupled with reproductive futurism, we see how pregnant migrants are doubly abjected, but also how jus soli and their unborn American fetus-ascitizen become a desperate line of last defense against anti-immigration assaults, desperate because in invoking that defense, we again de-humanize migrant women as merely "containers of citizens" and never citizens in their own right.

This contradiction shows how the figure of the fetal citizen is a site of struggle between what Natalie Cisneros (2013) calls "backwards uncitizening" - that is, for anti-immigration activists to attack jus soli in an attempt to erase the fetus' U.S. citizenship prior to its birth - and for migrant women and their supporters to sometimes resort to its opposite in asserting their claim on the nation. Cisneros argues that these attacks are temporally 'backwards' because they "appeal to a prior boundary of citizenship" that is racist, so as to "“naturalize" the denaturalization of United States citizens" (pages 303-304). She understates the point, however, that no matter how 'backwards' the racist constitution of citizenship seems, it is very much alive in the present and its proponents are always looking forward into the future (just as they were a century ago prior to Wong Kim Ark). And 
this overdetermined future, as a temporal mode of discipline in the present, means that the struggle over the fetal citizen is a lose-lose proposition for women, so long as both sides continue to actually accord the fetus its own citizenship at the expense of recognizing the pregnant woman's own.

This temporal mode of discipline in the present is reflected explicitly in media reports making the link between the Chino Hills controversy and existing national discourse on 'anchor babies' (e.g., Huffington Post, 2012). Of particular note is how anti-jus soli politics is publicly justified through the discourse of protecting fetal citizens, even though its political endgame is precisely to ensure that no such fetus will ever become U.S. citizens. 'Anchor baby', of course, is a derogatory term that has a prior history in U.S. immigration debates. In particular, it has both a racialized origin (Ignatow and Williams, 2011) and a dominant racist usage (Lederer, 2013), usually in reference to the supposed relationship between undocumented Latina mothers and their children born in the U.S. (i.e., supposedly, these children can 'anchor' their mothers to the U.S. by virtue of their own jus solibased citizenship). Anti-jus soli rhetoric draws from, and reinforces, existing anti-immigration politics vis-à-vis undocumented migrations, an entirely distinct practice from birth tourism. This racial dynamic further complicates anti-birth tourism organizing in southern California, as not all protestors oppose jus soli (though a great deal of them do), and media reports consistently clue in its readers and ask them to speculate - based on existing ideas about racial relations - why residents of particular ethnicities responded to birth tourism in the ways they did. So when articles on birth tourism end with punchlines like "It becomes personal, absolutely" from a Latino resident, readers are invited to arrive at a racialized explanation as to why it is personal for some residents and not others (Huffington Post, 2012).

Furthermore, opponents of birth tourism consistently expressed the sentiment that pregnant Chinese women are "stealing" from, or "cheating", the rest of us proper Americans in statements made to the press. For instance, Councilman Knabe repeatedly stated that maternity hotels are not regulated and, thus, their owners do not pay taxes to local governments; yet his statements were accompanied not by discussions on proper health and zoning regulations for such facilities, but instead on the issue of 'illegal immigrants' (Chang, 2013a; Sewell, 2013). Said differently, a slippage formed in these attacks, where pregnant Chinese women came to bear the brunt of scrutiny in place of maternity hotel operators. But what exactly did these women steal by giving birth in the U.S.? Following Berlant (1994), such expressions can only mean that these women are stealing a national future that never belonged to them. Jus soli might still leave their fetuses a claim on that national future, but it is not for these women; after all, they are seen as merely 'containers of citizens' and any 
such claim on their own is derivative (Cisneros, 2013). Accusations of "cheating", then, shows how their childbirth out of place amounts to a powerful interruption to that national fantasy of fetal citizenship (Berlant, 1994; 1993; see also Constable, 2014). By virtue of their own non-belonging, they appear to 'cheat' their own dehumanization in the age of fetality and transgress a reproductive futurism that is punitive to women like them (Berlant, 1994, page 149).

And what of this national future? In the most explicit call backwards to racist conceptions of U.S. citizenship, NICH's Mitchell said of Chinese families who utilize maternity hotels: “They don't pay taxes, they don't assimilate" (Chang, 2012b). In other words, to secure this fantasy of national future, such misfits must be excluded. This argument is a familiar one in anti-immigration organizing. Recall Natalie Cisneros' (2013, page 291) report on legislative debates in Tennessee, where state lawmakers accused Mexican women of "multiply[ing]... like rats" to take advantage of maternity benefits. In these scenarios, the unborn child's future U.S. citizenship offers some potential protection. In a scene right out of Berlant's (1994) age of fetality, Tennessee healthcare

officials - in order to work around certain women's potential undocumented status - argued that when they provide maternity care, they are caring for the unborn children and not the pregnant women since the unborns, by virtue of jus soli, “will be classified as U.S. citizen” regardless of their mothers' citizenship (Cisneros, 2013, page 291). These pro-jus soli calls have limited transgressive potential, but they also continue to foreclose possibility for emancipatory citizenship for all women. Racialized reproductive futurism, then, compels representations of both pro- and anti-birth tourism rhetorics to maintain the figure of the fetal citizen rather than recognizing women as full citizens in their own right.

\section{Discussion and conclusion}

In all media reports of the Chino Hills controversy, the fetus' U.S. citizen-ness is a crucial component in constructing political arguments, as opponents often relied on the figure of the fetal citizen to humanize their attacks on 'illegal immigrants' in maternity hotels in the region (Chang, 2013b). By tracing representations of Chinese birth tourism in U.S. immigration politics vis-à-vis birthright citizenship and 'anchor babies', this paper answers Mancini and Finlay's (2008, page 594) call for greater scholarly attention to not just citizenship, but jus soli specifically. Jus soli is a form of citizenship that is intimately tied to the territory, and there is an irony in the fact the most territorially bounded understanding of national citizenship is now a major source of anxiety for nation-states across the globe. The panic over Chinese birth tourism in southern California 
demonstrates how jus soli birthright citizenship, childbearing, and racialization come together, forcing nativists to struggle for a 'better' (i.e., whiter) future in 'America's Pacific century' (Clinton, 2011).

Considering reproductive futurism in concert with U.S. immigration politics suggests a dilemma. On the one hand, the state relies on the logic of fetality (and its extension in family reunification immigration policies) to exercise its biopolitical power - that is, to make live for certain populations - through criteria based on racialized citizenships (Lee, 2015; Ngai, 2005; 1999). Thus, it is possible for President Obama to order immigration judges to consider "family connections" in deportation proceedings, in response to immigration activists' calls to "stop deporting future [U.S.] citizens" (Wessler, 2013, emphasis added; see also Bhabha, 2009), or for health officials to continue caring for pregnant undocumented migrants by suggesting that they are really caring for their citizenfetus (and not the mothers; Cisneros, 2013). Although these actions provide potential relief for migrant families with U.S. citizen-children, they also shore up heteronormative and racist foundations of the state by linking inclusion in the present to a fetal citizenship based on the future. As Karma Chávez (2013) noted in the context of anti-deportation activism, when undocumented migrants facing deportation use their U.S. citizen child - born on U.S. soil - to argue for their reprieve, it becomes even more difficult to advance a structural critique of migrant detention for all migrant families, with or without U.S. citizen-children (pages 104-109). ${ }^{7}$ This dilemma is a hallmark of racialized reproductive futurism and shapes the contours of local responses to the Chino Hills controversy.

More generally, this paper demonstrates how temporalities - both the past and the future figure at the heart of political practices today. As geographers, we are naturally inclined to identify space, place, and scale as our objects of political analysis (Barnett and Low, 2004, page 9), but this paper demonstrates the utility of a method that focuses on temporality alongside geography (e.g., Massey, 1992; May and Thrift, 2001; Amin, 2010). By connecting the racialized history of U.S. citizenship to contemporary debates about citizenship policies, we see how contemporary anti-jus soli campaigns requires the production of an amnesia that presents the project of racial equality as already complete. Yet these temporal modes of abjection (such as Cisneros' [2013] "backwards uncitizening") are present now and extend into the future through racialized reproductive futurism. The child - or, in these biopolitical times, the fetus - is now a figure through which women as (future-)mothers are interpellated and disciplined (Berlant, 1994). The supposed concern for the

\footnotetext{
${ }^{7}$ In a similar vein, the always-brilliant Yasmin Nair (2011) discussed how the tired trope of 'worthy immigrants' functions in migrant organizing vis-à-vis the Shirley Tan case.
} 
well-being of Chinese women and their fetuses in the Chino Hills controversy, then, masks a complex history of immigrant incorporations and racial formations in southern California.

Textual analysis of media representations on birth tourism in this paper reveals jus soli and the figure of the fetal citizen as contradictory sites for struggles over the national future, though the terrain of these struggles is constantly shifting. The fetal citizen, in the hands of pro-jus soli advocates, has certain limited transgressive potentials, though these potentials remain limited as long as we accord fetuses recognition of citizenship at the expense of, or even in addition to, women who carry them. Examining the rhetoric against these ambiguously American subjects and the U.S. media's fixation on them as 'illegal' immigration helps us understand how struggles over reproduction is central to social controls, and reproductive futurism offers another analytic for examining the construction of political arguments in immigration debates.

Despite the pressing need to develop more thorough understanding of the birth tourism phenomenon on the ground, I have shown in this paper that birth tourism 'panic', as historically and geographically situated representations, depends on racialized reproductive futurism and citizenship in the U.S. This panic augments reproductive futurism's role in securing the fantasy of national future by abjecting women through the invention of the fetal citizen (Luibhéid, 2013; Berlant, 1994). More broadly, although xenophobic reporting on the Chino Hills controversy is just another episode in the longue durée of anti-Asian fear in the U.S. (Tchen and Yeats, 2014), analysis in this instance demonstrates that citizenship and temporality are two analytic categories essential in understanding contemporary immigration discourses in the U.S. 


\section{References}

Aber S, Small M, 2013, "Citizen or subordinate: permutations of belonging in the United States and the Dominican Republic" Journal on Migration and Human Security 1(3) 76-96

Aleinikoff T A, Klusmeyer D B, Eds, 2002 Citizenship Policies for an Age of Migration (Carnegie Endowment for International Peace, Washington, DC)

Amin A, 2010, "The remainders of race" Theory, Culture \& Society 27(1) 1-23

Amin A, 2013, "Surviving the turbulent future" Environment and Planning D: Society and Space 31(1) $140-156$

Baldwin A, 2012, "Whiteness and futurity" Progress in Human Geography 36(2) 172-187

Balta E, Altan-Olcay O, 2016, "Strategic citizens of America: transnational inequalities and transformation of citizenship" Ethnic and Racial Studies 39(6) 939-957

Barnett C, Low M, 2004, "Geography and democracy: an introduction”, in Spaces of Democracy: Geographical Perspectives on Citizenship, Participation and Representation Eds C Barnett, M Low (SAGE, London) pp 1-22

Bauder H, 2014, "Domicile citizenship, human mobility and territoriality" Progress in Human Geography 38(1) 91-106

Beech H, 2013, "I want an American baby! Chinese women flock to the U.S. to give birth" Time Magazine 27 November, http:/ / world.time.com/2013/11/27/chinese-women-are-flockingto-the-u-s-to-have-babies/

Berlant L, 1993, "The theory of infantile citizenship" Public Culture 5 395-410

Berlant L, 1994, “America, 'fat,' the fetus” boundary 2 21(3) 145-195

Berlant L, 1997 The Queen of America Goes to Washington City (Duke University Press, Durham, NC)

Bhabha J, 2009, "The 'mere fortuity of birth'? Children, mothers, borders, and the meaning of citizenship", in Migrations and Mobilities: Citizenship, Borders, and Gender Eds S Benhabib, J Resnik (New York University Press, New York, NY) pp 187-227

Bloemraad I, 2013, "Being American / becoming American: birthright citizenship and immigrants' membership in the United States" Studies in Law, Politics and Society 60 55-84

Bloemraad I, Korteweg A, Yurdakul G, 2008, "Citizenship and immigration: multiculturalism, assimilation, and challenges to the nation-state" Annual Review of Sociology 34 153-179

Buscher M, Urry J, 2009, "Mobile methods and the empirical” European Journal of Social Theory 12(1) 99-116

CAACH, 2012, "Chino Hills Chinese American Association Endorses Not in Chino Hills!” Chinese American Association of Chino Hills 17 December,

http://www.notinchinohills.org/chino_hills_chinese_american_association_endorses_not_i n_chino_hills

Chang C, 2012a, "Chino Hills maternity hotel controversy heats up" Los Angeles Times 11 December, http:/ / latimesblogs.latimes.com/lanow/2012/12/chino-hills-maternity-hotel-controversyheats-up.html

Chang C, 2012b, "Chino Hills seeks to close home used by pregnant Chinese women" Los Angeles Times 4 December, http://articles.latimes.com/2012/dec/04/local/la-me-birthing-center20121204

Chang C, 2013a, "Complaints against maternity hotels surge" Los Angeles Times 27 January, http://articles.latimes.com/2013/jan/27/local/la-me-birthing-centers-20130126

Chang C, 2013b, “L.A. County cites 16 'maternity hotel' owners" Los Angeles Times 11 April, http:/ / articles.latimes.com/2013/apr/11/local/la-me-ff-maternity-hotels-20130412

Chang C, 2013c, "Maternity hotel ordinance not necessary, planning department says" Los Angeles Times 28 October, http://articles.latimes.com/2013/oct/28/local/la-me-ln-maternity-hotelordinance-20131028 
Chávez K R, 2013 Queer Migration Politics: Activist Rhetoric and Coalitional Possibilities (University of Illinois Press, Urbana, IL)

Cheng W, 2013 The Changs Next Door to the Diazes: Remapping Race in Suburban California (University of Minnesota Press, Minneapolis, MN)

Cisneros J D, 2008, “Contaminated communities: the metaphor of 'immigrant as pollutant' in media representations of immigration" Rhetoric \& Public Affairs 11(4) 569-601

Cisneros N, 2013, “Alien' sexuality: race, maternity, and citizenship” Hypatia: A Journal of Feminist Philosophy 28(2) 290-306

Clinton H, 2011, “America's Pacific century” Foreign Policy 11 October, http://www.foreignpolicy.com/articles/2011/10/11/americas_pacific_century

Conlon D, 2010. "Ties that bind: governmentality, the state, and asylum in contemporary Ireland" Environment and Planning D: Society and Space 28(1) 95-111

Connell J, 2013, “Contemporary medical tourism: conceptualization, culture and commodification" Tourism Management 34 1-13

Constable N, 2014 Born Out of Place: Migrant Mothers and the Politics of International Labor (University of California Press, Berkeley, CA)

Cresswell T, 2006 On the Move: Mobility in the Modern Western World (Routledge, London)

de Beauvoir S, 1989 The Second Sex (Vintage, New York)

Edelman L, 2004 No Future: Queer Theory and the Death Drive (Duke University Press, Durham, NC)

Ellis M, 2006, "Unsettling immigrant geographies: US immigration and the politics of scale" Tijdschrift voor economische en sociale geografie 97(1) 49-58

Ellis M, Wright R, Townley M, 2014 "The Great Recession and the allure of new immigrant destinations in the United States" International Migration Review 48(1) 3-33

Eng D L, 2010 The Feeling of Kinship: Queer Liberalism and the Racialization of Intimacy (Duke University Press, Durham, NC)

Enloe C, 1990, "Women and children: making feminist sense of the Persian Gulf Crisis" The Village Voice 25 September

Glenn E, 2000, "Citizenship and inequality: historical and global perspectives" Social Problems 47(1) $1-20$

Hannerz U, 2003, "Being there... and there... and there! Reflections on multi-site ethnography" Ethnography 4(2) 201-216

Hartry A S, 2012, "Birthright justice: the attack on birthright citizenship and immigrant women of color" NYU Review of Law \& Social Change 36(1) 57-101

Hoeffel E M, Rastogi S, Kim M O, Shahid H, 2012, “The Asian population: 2010” 2010 Census Briefs (U.S. Census Bureau, Washington, DC)

Huffington Post, 2012, “"Maternity hotel' in Chino Hills, Calif. sparks outrage, reports of other maternity tourism businesses" 12 December, http:/ /www.huffingtonpost.com/2012/12/12/maternity-hotel-chino-hills-calif-asianmothers-video_n_2286372.html

Ignatow G, Williams A T, 2011, "New media and the 'anchor baby' boom” Journal of ComputerMediated Communication 17(1) 60-76

Isin E F, 2012, "Citizens without nations" Environment and Planning D: Society and Space 30(3) 450-467

Jacobson L, 2010, "Fact-checking the claims about 'anchor babies' and whether illegal immigrants 'drop and leave" " PolitiFact.com 6 August, http://www.politifact.com/truth-ometer/statements/2010/aug/06/lindsey-graham/illegal-immigrants-anchor-babiesbirthright/

Jones R C, 2008, "The ambiguous roles of suburbanization and immigration in ethnic segregation: the case of San Antonio" Urban Geography 29(3) 196-223 
Katz C, 2008, "Childhood as spectacle: relays of anxiety and the reconfiguration of the child" cultural geographies 15(1) 5-17

Katz C, 2011, "Accumulation, excess, childhood: toward a countertopography of risk and waste" Documents d'Anàlisi Geogräfica 57(1) 47-60

Kerber L K, 2009, “The stateless as the citizen's other: a view from the United States”, in Migrations and Mobilities: Citizenship, Borders, and Gender Eds S Benhabib, J Resnik (New York University Press, New York, NY) pp 76-123

Koch N, 2013, “Technologising the opinion: focus groups, performance and free speech" Area 45 411-418

Koch N, in press, "Is nationalism just for nationals? Civic nationalism for noncitizens and celebrating National Day in Qatar and the UAE" Political Geography doi:10.1016/j.polgeo.2015.09.006

Lederer J, 2013, “"Anchor baby': a conceptual explanation for pejoration” Journal of Pragmatics 57 $248-266$

Lee C, 2015, "Family reunification and the limits of immigration reform: impact and legacy of the 1965 Immigration Act" Sociological Forum 30 528-548

Levitt P, Jaworsky B N, 2007, "Transnational migration studies: past developments and future trends" Annual Review of Sociology 33 129-56

Li W, 1998, "Anatomy of a new ethnic settlement: the Chinese ethnoburb in Los Angeles" Urban Studies 35(3) 479-501

Li W, 1999, "Building ethnoburbia: the emergence and manifestation of the Chinese ethnoburb in Los Angeles' San Gabriel Valley" Journal of Asian American Studies 2(1) 1-28

Li W, 2009 Ethnoburb: The New Ethnic Community in Urban America (University of Hawai'i Press, Honolulu, HI)

Lin J, Robinson P, 2005, "Spatial disparities in the expansion of the Chinese ethnoburb of Los Angeles" GeoJournal 64(1) 51-61

Lin W, 2012, "Beyond flexible citizenship: towards a study of many Chinese transnationalisms" Geoforum 43 137-146

Liu L Y, 2000, "The place of immigration in studies of geography and race” Social \& Cultural Geography 1(2) 169-182

Lu R, 2014, "Look who's walking: Chinese birth tourism goes stateside” Foreign Policy 25 April, http://www.foreignpolicy.com/articles/2014/04/25/chinese_birth_tourism_on_rise_in_us a

Luibhéid E, 2013 Pregnant on Arrival: Making the Illegal Immigrant (University of Minnesota Press, Minneapolis, $\mathrm{MN}$ )

MacDonald K, 2016, "Calls for educating girls in the Third World: futurity, girls and the 'Third World Woman"' Gender, Place \& Culture 23(1) 1-17

Mancini J M, Finlay G, 2008, “Citizenship matters': lessons from the Irish citizenship referendum” American Quarterly 60(3) 575-599

Mas S, 2014, "Canadian citizenship rules face broad reform in 2014" CBC News 24 January, http://www.cbc.ca/news/politics/canadian-citizenship-rules-face-broad-reform-in-20141.2508758

Massey D, 1992, "Politics and space/time" New Left Review 65-84

Massey D S, Ed, 2008 New Faces in New Places: The Changing Geography of American Immigration (Russell Sage, New York, NY)

May J, Thrift N, Eds, 2001 Timespace: Geographies of Temporality (Routledge, London)

Medina J, 2011, “Arriving as pregnant tourists, leaving with American babies” New York Times 28 March, http:/ /www.nytimes.com/2011/03/29/us/29babies.html 
Menzel A, 2013, "Birthright citizenship and the racial contract: the United States' jus soli rule against the global regime of citizenship" Du Bois Review 10(1) 29-58

Mitchell K, 1998, "Reworking democracy: contemporary immigration and community politics in Vancouver's Chinatown" Political Geography 17(6) 729-750

Mitchell K, 2010, "Pre-black futures" Antipode 41 239-261

Molina N, 2014 How Race is Made in America: Immigration, Citizenship, and the Historical Power of Racial Scripts (University of California Press, Berkeley, CA)

Nair Y, 2011, "How to make prisons disappear: queer immigrants, the shackles of love, and the invisibility of the prison industrial complex", in Captive Genders: Trans Embodiment and the Prison Industrial Complex Eds E A Stanley, N Smith (AK Press, Oakland, CA) pp 123-139

Ngai M M, 1999, "The architecture of race in American immigration law: a reexamination of the Immigration Act of 1924" The Journal of American History 86(1) 67-92

Ngai M M, 2005 Impossible Subjects: Illegal Aliens and the Making of Modern America (Princeton University Press, Princeton, NJ)

Ngai M M, 2007, "Birthright citizenship and the alien citizen" Fordham Law Review 75(5) 2521-2530

Ochoa G L, 2004 Becoming Neighbors in a Mexican American Community: Power, Conflict, and Solidarity (University of Texas Press, Austin, TX)

Oliviero K E, 2013, "The immigration state of emergency: racializing and gendering national vulnerability in twenty-first century citizenship and deportation regimes" Feminist Formations 25(2) 1-29

Ong A, 1999 Flexible Citizenship: The Cultural Logics of Transnationality (Duke University Press, Durham, NC)

Pandit K, Holloway S R, 2005, "New immigrant geographies of United States metropolitan areas" Geographical Review 95(2) iii-vi

PBS, 2013, "New Americans" Public Broadcasting Company 17 May, http://video.pbs.org/video/2365013663/

Price P L, 2012, "Race and ethnicity: Latino/a immigrants and emerging geographies of race and place in the USA" Progress in Human Geography 36(6) 800-809

Pulido L, Barraclough L, Cheng W, Eds, 2012 A People's Guide to Los Angeles (University of California Press, Oakland, CA)

Roberts D E, 1998, "Who may give birth to citizens? Reproduction, eugenics, and immigration" Rutgers Race and the Law Review 1 129-136

Roberts E F S, Scheper-Hughes N, 2011, "Introduction: medical migrations” Body \& Society 17(2\&3) $1-30$

Rojas L B, 2013, “Asian-Americans become a more prominent voice in immigration debate” Southern California Public Radio 2 August, http://www.scpr.org/blogs/multiamerican/2013/08/02/14422/asian-americans-become-amore-prominent-voice-in-i/

Sadiq K, 2008 Paper Citizens: How Illegal Immigrants Acquire Citizenship in Developing Countries (Oxford University Press, Oxford)

Saito L T, 1998 Race and Politics: Asian Americans, Latinos, and Whites in a Los Angeles Suburb (University of Illinois Press, Champaign, IL)

Schuck P H, Smith R M, 1985 Citizenship Without Consent: The Illegal Alien in the American Polity (Yale University Press, New Haven, CT)

Sewell A, 2013, "L.A. supervisors approve task force to examine 'maternity hotels' " Los Angeles Times 5 February, http://latimesblogs.latimes.com/lanow/2013/02/maternity-hotels.html

Shachar A, 2009 The Birthright Lottery: Citizenship and Global Inequality (Harvard University Press, Cambridge, MA) 
Singer A, Hardwick S W, Brettell C B, Eds, 2008 Twenty-First Century Gateways: Immigrant Incorporation in Suburban America (Brookings, Washington, DC)

Smith B E, Winders J, 2008, “We're here to stay”: economic restructuring, Latino migration and place-making in the US South" Transactions of the Institute of British Geographers 33(1) 60-72

Smith M P, 2005, "Power in place/places of power: contexualizing transnational research" City \& Society 17(1) 5-34

Somerville S B, 2005, "Notes toward a queer history of naturalization" American Quarterly 57(3) 659_ 675

South El Monte Arts Posse, 2014, "A brief history (and geography) of the San Gabriel Valley" Tropics of Meta 3 February, http://tropicsofmeta.wordpress.com/2014/02/03/a-briefhistory-and-geography-of-the-san-gabriel-valley/

Stevens J, 2009 States without Nations: Citizenship for Mortals (Columbia University Press, New York, NY)

Tchen J K W, Yeats D, Eds, 2014 Yellow Peril! An Archive of Anti-Asian Fear (Verso, London)

Templeton R, 2010, "Baby baiting” The Nation 29 July, http://www.thenation.com/article/38035/baby-baiting

Tobar H, 2011, "“Anchor baby' myth is pure fear-mongering” Los Angeles Times 4 February, http:/ /articles.latimes.com/2011/feb/04/local/la-me-0204-tobar-20110204

Tormey A, 2007, “'Everyone with eyes can see the problem': moral citizens and the space of Irish nationhood" International Migration 45(3) 69-100

Tseng Y, 1994, "Chinese ethnic economy: San Gabriel Valley, Los Angeles County" Journal of Urban Affairs 16(2) 169-189

Tyler I, 2010, "Designed to fail: a biopolitics of British citizenship" Citizenship Studies 14(1) 61-74

Wessler S F, 2013, “Advocates to Obama: stop deporting future citizens" Colorlines 13 May, http://colorlines.com/archives/2013/05/advocates_to_obama_stop_deporting_future_citiz ens.html

Wong J, 2014, "Canada's birthright citizenship policy makes us a nation of suckers” Toronto Life 20 May, http://www.torontolife.com/informer/columns/2014/05/20/jan-wong-canadabirthright-citizenship-nation-of-suckers/

Yam S S, in press, "Affective economies and alienizing discourse: citizenship and maternity tourism in Hong Kong” Rhetoric Society Quarterly doi:10.1080/02773945.2016.1159721

Zhou M, Tseng Y, Kim, R Y, 2008, "Rethinking residential assimilation: the case of a Chinese ethnoburb in the San Gabriel Valley, California" Amerasia Journal 34(3) 53-83 